\title{
PEREMPUAN DAN GAYA HIDUP BARAT DI KOTA YOGYAKARTA PADA AWAL KEMERDEKAAN INDONESIA
}

\author{
WOMEN AND WESTERN LIFESTYLE \\ IN YOGYAKARTA AT THE BEGINNING OF THE \\ INDONESIAN INDEPENDENCE ERA
}

\author{
Hervina Nurullita dan Hendra Afiyanto \\ Universitas PGRI Banyuwangi dan IAIN Tulungagung \\ Jln. Ikan Tongkol No.1, Banyuwangi, Indonesia
}

Diterima tanggal 14 September 2020

Disetujui tanggal 17 Desember 2021

\begin{abstract}
The article came as the inheritance reconstruction of the colonial effect phenomenon in Yogyakarta after the declaration of independence. It is interesting to discuss how the people of Yogyakarta show an anti-Netherland attitude toward colonial heritage, which is interpreted widely as anticolonial and anti-Netherland, but accept western lifestyle in daily life. The spread of western lifestyles makes Yogyakarta women begin to reconstruct culture to look for a new identity in their life which is paradoxical with the mainstream attitude and behavior of Yogyakarta people at the beginning of Independence Day. The paper aims to explain the acceptance of women in Yogyakarta to western lifestyles in daily life amidst the strengthening of anti-western sentiment. This paper presents the historical study result using the historical method with the stage of heuristics, criticism, interpretation, and historiography. This study used modernization theory. Modernization has a significant influence on the easy access of women in Yogyakarta to keep up with the times. The study shows how western lifestyles grew and became a trend of women's appearance in Yogyakarta at that time.
\end{abstract}

Keywords: women, western lifestyle, modernity, and Yogyakarta.

\begin{abstract}
ABSTRAK
Tulisan ini muncul sebagai rekonstruksi atas pewarisan fenomena colonial effect yang terjadi di Yogyakarta pasca kemerdekaan. Hal menarik ketika masyarakat Yogyakarta menunjukkan sikap anti-Belanda, yang dimaknai secara luas sebagai antikolonial dan anti-Barat, terhadap warisan kolonial tetapi menerima gaya hidup Barat yang digunakan dalam kehidupan seharihari. Masifnya gaya hidup Barat membuat perempuan di Kota Yogyakarta mulai merekonstruksi budaya dalam kehidupan mereka untuk mencari identitas baru yang terbilang paradoks dengan arus utama sikap dan perilaku masyarakat Yogyakarta pada awal kemerdekaan. Tujuan kajian ini adalah untuk menjelaskan penerimaan perempuan di Kota Yogyakarta terhadap gaya hidup Barat dalam kehidupan sehari-hari di tengah menguatnya
\end{abstract}


sentimen anti-Barat. Tulisan ini adalah hasil kajian sejarah yang disusun menggunakan metode sejarah dengan tahapan heuristik, kritik, interpretasi, dan historiografi. Konsep yang digunakan dalam kajian ini adalah konsep modernitas. Modernisasi membawa pengaruh yang besar terhadap kemudahan akses bagi perempuan Yogyakarta untuk mengikuti perkembangan zaman. Hasil kajian menunjukkan gaya hidup Barat tumbuh dan menjadi tren penampilan perempuan di Kota Yogyakarta pada masa itu.

Kata kunci: perempuan, gaya hidup Barat, modernisasi, dan Yogyakarta.

\section{A. PENDAHULUAN}

Lama menunggu-nunggu. Modiste Dewi masih tutup. Sedang waktu keberangkatan telah mendesak." (Minggu Pagi 1951)

...Aku sudah mendapat nomer korsi bioskop. Nomer 13. Aku lalu mencari nomer korsiku, tetapi di sana telah ada jang menduduki jaitu seorang perempuan jang sudah tua...dan korsi nomer 14 ditempati seorang anak gadis."

(Minggu Pagi 1952)

Kutipan pada majalah Minggu Pagi yang terbit di Yogyakarta tahun 1950an di atas rasanya sesuai untuk menggambarkan kehidupan sehari-hari perempuan terkait perubahan gaya hidup yang terjadi di Kota Yogyakarta pada awal kemerdekaan Indonesia.

Ani Idrus dalam kunjungannya ke Yogyakarta pada 1950an mengatakan bahwa pakaian perempuan Yogyakarta cukup necis dengan perhiasan peraknya (Idrus 1952). Penampilan seperti itu cukup sering dijumpai di Yogyakarta mulai awal 1950an. Fenomena ini cenderung kontradiktif dengan budaya yang hidup di Kota Yogyakarta kala itu, yakni budaya Jawa yang patriarki yang melihat perempuan sebagai makhluk nomor dua dan mendiskriminasi peran mereka dalam masyarakat (Pranowo
2013:56). Dengan budaya semacam itu, kehadirannya cenderung tidak akan menonjol dan menarik perhatian.

Kebiasaan baru perempuan dengan penampilan Barat yang ditemui di Kota Yogyakarta awal 1950an dipandang sebagai awal suburnya gaya hidup Barat pasca kemerdekaan. Gaya hidup Barat awalnya sebagai simbol kebiasaan masyarakat kolonial. Masyarakat kolonial mewariskannya melalui kebiasaan dan status sosial. Adanya stratifikasi sosial yang diakibatkan olehnya, memunculkan standar kegiatan yang dilakukan oleh masyarakat Eropa lebih bernilai derajat tinggi (Soemardjan 2009:43).

Maraknya adopsi gaya hidup Barat pada perempuan Yogyakarta pada awal 1950an menjadi sebuah fenomena yang menarik. Gaya hidup Barat tumbuh sebagai roh dari kehidupan sehari-hari perempuan Yogyakarta. Di satu sisi, perempuan pengguna gaya hidup Barat dimaknai sebagai perempuan yang mampu melompati pagar domestikasinya (Khasanah dan Afiyanto 2017:159). Di sisi lain, pengguna budaya tinggi Jawa menganggap gaya hidup Barat adalah budaya substandar. Mereka mengalienasi pengguna gaya hidup Barat dengan label sebagai perempuan yang mengingkari perannya. Alhasil pada 
awal 1950an bermunculan pro dan kontra pada masyarakat Yogyakarta terkait penggunaan gaya hidup Barat oleh kaum perempuan.

Diskusi tentang fenomena gaya hidup Barat bagi perempuan di Kota Yogyakarta tidak bisa dilepaskan dari kajian sejarah, sosiologis, dan antropologis. Gaya pakaian dan gaya hidup perempuan menjadi dua variabel modernitas yang terjadi di Yogyakarta. Studi sosial yang ditinjau meliputi kajian tentang kependudukan, seperti jumlah penduduk Yogyakarta yang telah mengenyam pendidikan tinggi, terutama kaum perempuan. Dengan melihat data perempuan yang melanjutkan pendidikan di perguruan tinggi, dapat dilihat bagaimana perempuan telah melompati pagar domestikasi dan lebih mudah mengakses modernitas.

Identifikasi gaya hidup perempuan yang paling mudah dilihat adalah mode pakaian. Amini, dan Nurhajarini melihatnya dalam sudut pandang yang berbeda. Amini (2005) melihat kontes mode sebagai kemampuan perempuan melompati pagar domestikasinya. Tidak hanya pada tingkat aktivitas ruang domestik, tetapi juga ruang publik. Kontes mode oleh perempuan Yogyakarta dimaknai sebagai simbolisasi diri dari status pelajar dan pekerja. Sayangnya, karya ini kurang memperlihatkan proses perkembangan penampilan perempuan, meski cukup baik dalam mengonstruksi penampilan perempuan Yogyakarta pada 1950-1960an. Analisis perkembangan pakaian perempuan Jawa ditulis oleh Nurhajarini (2003). Tulisannya menjelaskan awal mula simbolisasi pakaian perempuan Jawa berupa kebaya, kain, stagen, selendang, konde, dan alas kaki. Bagian-bagian pakaian ini dalam perkembangannya mendapat pengaruh dari Barat. Unsur pakaian Barat yang pertama kali diadopsi adalah aksesori. Penggunaan aksesori dikombinasikan dengan baju-baju kebaya dilakukan oleh keluarga keraton. Selanjutnya kelompok di luar keraton yang memulai menggunakan baju bergaya Barat adalah mereka yang belajar pada sekolah misi atau zending. Proses adopsi tersebut disimpulkan Nurhajarini sebagai proses menghilangnya pamor kebaya sebagai pakaian keseharian perempuan golongan menengah dan atas. Sudut pandang karya ini membantu penulis dalam melihat sejarah perkembangan pakaian Jawa.

Pemaknaan pakaian sebagai satu kesatuan dari tubuh manusia yang membentuk identitas, kelas, dan status dilakukan oleh Taylor (2005) dengan baik. Walaupun memfokuskan bahasan pada penampilan laki-laki, ketiga hal tersebut dilihat Taylor pada orang-orang pribumi yang mencoba menjadi dan ingin diperlakukan layaknya orang Barat melalui mode pakaian yang digunakan.

Makna dan identitas ditampilkan Afiyanto (2017) dalam membahas tentang pemaknaan ulang penampilan perempuan Yogyakarta. Penampilan masyarakat Yogyakarta pascawesternisasi dan mengagamakan memunculkan kebaruan yang luar biasa. Eksistensi penampilan ala Belanda tetap berlanjut hingga sekarang. Adanya semangat anti-kolonial nyatanya tidak bisa membendung serbuan westernisasi. Masyarakat Yogyakarta 
Handep Jurnal Sejarah dan Budaya Vol. 5, No. 1, Desember 2021, hlm. 97-110

menganggap penampilan merupakan irisan besar dari rangkaian kehidupan sehari-hari yang lumrah sehingga semangat antikolonial (pemutusan dan penghancuran simbol-simbol kolonialisme) tidak bisa menembus sekat-sekat serbuan budaya pembaratan.

Studi-studi tersebut menghimpun kehidupan perempuan yang telah mendapatkan pengaruh gaya hidup Barat dalam kehidupan sehari-hari. Fokus isu tersebut dikemas dalam pendekatan sejarah perempuan. Untuk itu, artikel ini menggunakan pendekatan yang ditawarkan oleh Scott (1988) meliputi pendekatan secara kronologi dan pendekatan kausal. Peran kausal yang diperankan oleh perempuan Yogyakarta dianalisis melalui tindakannya dalam lingkungan sosiokulturalnya. Dengan demikian, pemahaman akan kausalitas yang melatarbelakangi ide dan bentuk perilaku yang diekspresikan oleh perempuan Yogyakarta dapat diperoleh.

Latar belakang di atas mengerucut pada pertanyaan tentang bagaimana dan mengapa terjadi pemaknaan ulang gaya hidup Barat dalam keseharian perempuan Yogyakarta di era awal kemerdekaan Indonesia. Tujuan penulisan artikel ini secara garis besar ingin melihat perilaku perempuan di Yogyakarta yang berparadoks dengan arus utama perilaku anti kolonial masyarakat di Yogyakarta. Anti kolonial tersebut dimaknai secara luas sebagai anti-Barat. Adapun pertanyaan tersebut akan dibahas dalam kerangka perempuan, ${ }^{1}$ gaya hidup Barat, dan modernitas.

Perempuan yang dimaksud dalam tulisan ini adalah perempuan yang tinggal di Yogyakarta, baik perempuan asli Yogyakarta maupun perempuan dari luar Yogyakarta yang ditemukan dalam sumber baik arsip, koran, maupun majalah. Lingkup perempuan dibatasi pada perempuan muda atau pemudi². Pemudi yang dipilih adalah pribumi yang menempuh pendidikan dari tingkat dasar, menengah, atas, hingga tinggi.

Gaya hidup Barat, seperti produk kecantikan dan gaya hidup, adalah warisan yang dibawa oleh orang Belanda (secara umum Eropa) ke Yogyakarta. Pada kehidupan perempuan di Kota Yogyakarta pada awal 1950an, gaya hidup Barat adalah kebiasaan baru yang berkembang

\footnotetext{
${ }^{1}$ Kata perempuan dipilih sesuai dengan penyebutan dalam surat kabar kala itu. Surat kabar dan majalah umumnya menggunakan kata prampoen atau prempuan, bukan wanita. Penyebutan kata perempuan juga dirasa lebih halus daripada kata wanita. Kata perempuan berasal dari kata empu yang bermakna dihargai, dipertuan, atau dihormati, sedangkan kata wanita diyakini dari bahasa Sanskerta, dengan kata dasar wan yang berarti nafsu. Dengan demikian, kata wanita memiliki arti yang dinafsui atau objek seks, yang dalam bahasa Jawa (Jawa Dorsok) kata wanita berarti berani ditata (Amini 2003:5)

${ }^{2}$ Istilah pemudi diartikan sebagai perempuan muda atau remaja putri. Remaja dalam bahasa Latin adalah adolesence yang artinya tumbuh. Menurut Rumini dan Sundari (2004:53), masa remaja adalah masa perkembangan dari mulai anak sampai dewasa yang menyangkut semua aspek baik fisik atau psikologi. Periode pemudi atau remaja ini berlangsung dari usia 10-22 tahun.
} 
sebagai tuntutan gaya hidup perkotaan (Amini 2005:2). Gaya hidup tersebut terekam dalam media berupa perempuan berwisata, membaca buku, bernyanyi, dan bermain alat musik (Majalah Gadjah Mada 1956).

Aktualisasi gaya hidup Barat dari kehidupan sehari-hari perempuan merupakan wujud modernitas di Yogyakarta. Menurut Nordholt (2011:435), modernitas merupakan sesuatu yang kontradiktif tidak saja bagi pihak kolonial tapi juga bagi bumiputra. Dari sudut pandang kolonial, Nordholt melihat modernitas sebagai sebuah sarana yang diciptakan pemerintah dalam proses pembentukan koloni yang lebih beradab. Dalam konteks ini beradab dimaknai sebagai superioritas budaya Barat dan keterbelakangan budaya bumiputra.

Proses pembaratan ini berkembang menjadi idealisasi gaya hidup modern Eropa perkotaan yang banyak diimpikan oleh bumiputra. Modernitas yang hadir dalam bentuk penampilan, selera, dan kualitas hidup menjadi bagian penting dalam proses pembentukan identitas dan status. Kenyataan ini menarik dibahas terutama dalam konteks perilaku perempuan yang mengikuti gaya hidup Barat di Yogyakarta pada awal era kemerdekaan Indonesia.

\section{B. METODE}

Kajian ini menggunakan metode sejarah yang terdiri atas empat tahapan yaitu pencarian sumber, kritik sumber, interprestasi, dan historiografi.

Sumber yang digunakan adalah sumber tertulis yakni majalah dan surat kabar. Penelusuran sumber dikerjakan di Arsip Daerah Provinsi Yogyakarta, Perpustakaan Daerah Yogyakarta, Library Centre Yogyakarta, Perpustakaan Ignatius Yogyakarta, Perpustakaan Fakultas Ilmu Budaya Universitas Gadjah Mada, Perpustakaan Universitas Gadjah Mada, dan Pusat Studi Kependudukan Universitas Gadjah Mada.

Majalah dan surat kabar yang digunakan tidak hanya terbitan Yogyakarta, tetapi juga dari luar Yogyakarta yang memuat penampilan masyarakat Yogyakarta pada tahun 1950an-1970an. Penelusuran data mendapatkan data terkait tema gaya hidup, kebiasaan, pakaian yang berkembang saat itu, seperti foto, iklan, artikel cerpen, tulisan pembaca, rubrik perempuan, mahligai puteri, materi tentang tata rias dan tata busana dan pergaulan dengan laki-laki. Artikelartikel tentang data tersebut ditemukan dalam majalah-majalah seperti Minggu Pagi, Wasita, Madjalah Ibu, Kedaulatan Rakyat, Majalah Gadjah Mada, dan Sinpo.

Sumber berupa foto merupakan sumber penting karena mencerminkan persepsi tentang masa lalu. Foto-foto yang dicari dan dikumpulkan adalah foto penduduk perempuan di area pendidikan dan publik. Foto di area pendidikan yang ditemukan adalah foto peristiwa di sekolah sedangkan foto di area publik yang dimaksud adalah foto organisasi, kongres, aktivitas seharihari, dan acara kontes. Foto-foto dan ilustrasi tentang kebiasaan, hobi baru, pakaian, perilaku, model rambut yang dijumpai di majalah membantu penulis dalam menafsirkan gaya hidup Barat dan perempuan di Yogyakarta. 
Setelah sumber-sumber terkumpul, langkah selanjutnya adalah kritik sumber. Kritik sumber dilakukan terhadap artikel dan berita dalam koran maupun majalah. Orientasi ideologi koran dan majalah perlu ditinjau agar pembahasan tentang gaya hidup Barat dan perempuan tidak dilihat sebagai sebuah kajian tunggal dan berdiri sendiri namun selalu berelasi dengan aspek-aspek sosial, politik dan ekonomi di sekitarnya. Sebagaimana sumber lain, beragam foto perlu melalui proses kritik yang teliti dengan pemahaman konteks yang tepat.

Langkah selanjutnya adalah interpretasi. Interpretasi dilakukan dengan cara mengaitkan fakta yang telah ditemukan dalam sumber-sumber.

Langkah terakhir adalah historiografi. Historiografi adalah proses penulisan kisah perempuan dan gaya hidup Barat di Kota Yogyakarta tahun 1950an.

\section{HASIL DAN BAHASAN}

1. Semangat Anti Kolonial dan Gaya Hidup Perempuan di Yogyakarta Tahun 1950an

Menjelang medio abad ke-20 atau lebih tepatnya tahun 1940an, kebencian masyarakat koloni terhadap pemerintahan kolonial semakin meningkat. Gaung kemerdekaan mulai memuncak seiring dengan bangkitnya kaum intelektual sebagai pemantik tokohtokoh nasionalis dimulai oleh Boedi Oetama sebagai organisasi nasional pertama. Lebih jauh, suburnya organisasi nasional yang berorientasi ke arah kemerdekaan Indonesia membawa arus semangat anti kolonial pada masyarakat koloni, mulai dari tingkat keresidenan, gemeente, district, hingga onderdistrict.

Kebencian masyarakat koloni terhadap pemerintah kolonial mewujud dalam beragam wajah. Umumnya, simbol fisik kolonial menjadi sasaran amuk kebencian dari masyarakat koloni di Hindia-Belanda. Hal ini bisa dilihat di Yogyakarta berupa penghancuran puluhan bangunan pabrik gula kolonial Hindia-Belanda oleh masyarakat koloni (Soemardjan 2009:309). Vandalisme pada bangunan kolonial juga dilakukan dengan mencoretkan tulisan-tulisan bernada pekik kemerdekaan dan umpatan-umpatan anti-kolonialisme sebagai wujud kebencian. Fenomena anti kolonial tersebut berlangsung pada kurun pra-kemerdekaan hingga pascakemerdekaan.

Laiknya negara baru merdeka, keinginan dari masyarakat Indonesia untuk melepaskan diri dari simbol kolonialisme sungguh besar. Namun di sisi lain, semangat anti kolonial yang memuncak tersebut membuat masyarakat koloni tidak mampu membedakan anti-kolonial dalam simbol fisik dan non fisik. Hal ini terlihat dari penerimaan gaya hidup Barat yang sudah menjadi kebiasaan dan berakulturasi dengan gaya hidup keseharian masyarakat. Pada ranah ini, perempuan di Yogyakarta menjadi objek yang paling dekat dengan simbolsimbol pembaratan tersebut.

Kuatnya pengaruh gaya hidup Barat yang dibawa oleh orde kolonial berimplikasi pada terwariskannya budaya tersebut pada keseharian perempuan Yogyakarta. Di tahun 1920an, adopsi budaya kolonial sudah dilakukan melalui lembaga pendidikan. 
Peran jongos atau babu yang bekerja di keluarga Belanda atau masyarakat Eropa lainnya turut menjadi agen di dalam penyebaran gaya hidup Barat tersebut (Kedaulatan Rakjat 1947; Sinpo 1941). Hal tersebut membuat nilai modernitas masuk ke dalam berbagai macam sektor kehidupan perempuan Yogyakarta. Modernitas yang dibawa oleh orde kolonial melekat kuat dengan budaya tinggi.

Kisaran tahun 1950an, serbuan budaya whitening masuk secara masif ke Yogyakarta. Beberapa terbitan di Yogyakarta pada kurun waktu pra-kemerdekaan hingga pascakemerdekaan turut mempromosikan budaya whitening tersebut dengan menampilkan foto model-model Eropa berkulit putih di berbagai macam terbitan, seperti Kedaulatan Rakjat 3 Januari 1950.

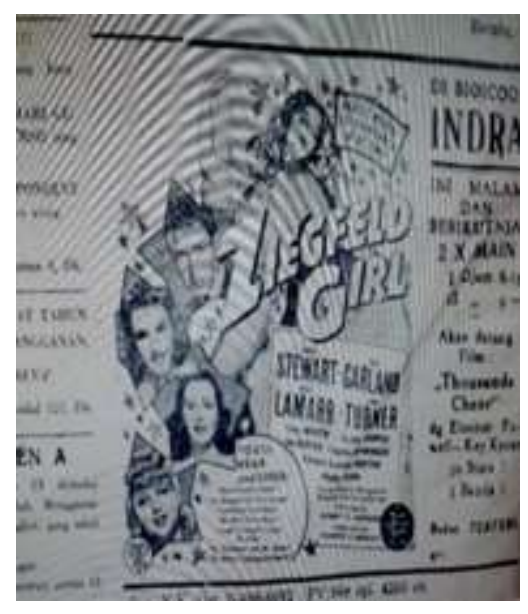

Gambar 1. Iklan produk pemutih.

Sumber: Kedaulatan Rakjat 3 Januari 1950.

Selain iklan produk pemutih dan kecantikan, iklan-iklan bioskop, dan kalimat persuasif dari salon untuk melayani riasan dan dandanan seperti layaknya orang Eropa, menunjukkan bahwa media mampu menumbuhkan beberapa wujud budaya yang diserap masyarakat serta menjadikannya kebiasaan (Strinati 2004:31). Modistemodiste yang dibanjiri pesanan pakaian ala Eropa menjadi bukti empiris hegemoni dan adopsi yang memengaruhi kehidupan perempuan perkotaan Yogyakarta. (Kedaulatan Rakjat 1952).

Kota menjadi ruang nyata untuk melihat bagaimana dua hal yang berbeda berjalan serasi (Colombijn dan Coté 2014). Tingginya pengguna gaya hidup Barat oleh perempuan Yogyakarta nyatanya selain karena faktor simbol ekspresi perempuan, juga karena perempuan Yogyakarta menikmati budaya tersebut. Beberapa artikel pada masa tersebut memberitakan kelebihnyamanan perempuan Yogyakarta dalam menggunakan pakaian terusan daripada pakaian kebaya dan jariknya di ruang publik. Kemudahan mobilitas menjadi alasan kenyamanan ini.

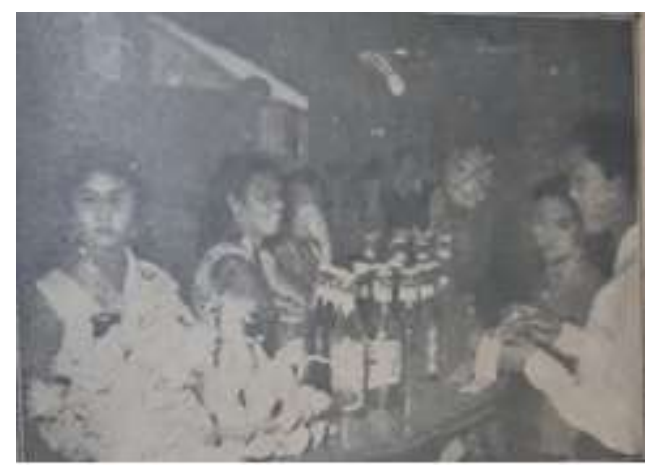

Gambar 2. Salah satu bar di Yogyakarta yang banyak peminatnya. Sumber: Madjalah Gadjah Mada November 1954.

Proses pemaknaan ulang gaya hidup tentu tidak berlangsung dengan tiba-tiba. Perempuan Yogyakarta tidak langsung meninggalkan identitas mereka dalam berpenampilan. Batik, lurik, tetap menghiasi pakaian terusan 
Handep Jurnal Sejarah dan Budaya Vol. 5, No. 1, Desember 2021, hlm. 97-110

mereka, meskipun hanya sebagai motif. Lurik tidak hanya bisa dibuat untuk kebaya, tetapi dapat juga digunakan sebagai pakaian modern seperti rok, pakaian harian, pakaian pesta, pakaian anak-anak, dan lain-lain. Foto model dengan baju berbahan lurik yang ditampilkan dalam Lurik Show Yogyakarta pada 1959 menunjukkan kenyataan tersebut (Madjalah Ibu 1959).

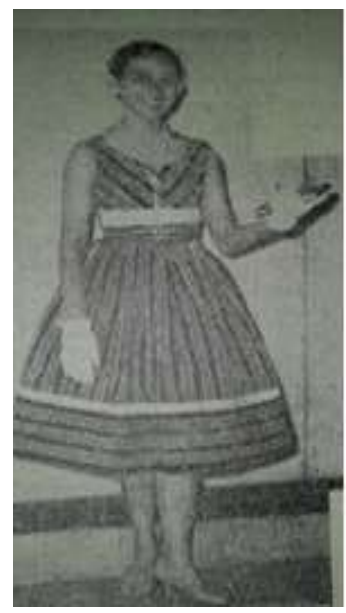

Gambar 3. Lurik Show. Sumber: Madjalah Ibu 1959.

Fenomena gaya hidup Barat kerap terlihat dalam pemberitaan surat kabar di Yogyakarta pada 1950an yang melaporkan bahwa dari sepuluh orang yang lewat jalan Malioboro, maka delapan orang di antaranya pasti menggunakan budaya "Belanda" (Minggu Pagi 1951). Demikian pula dalam seni hiburan, pertunjukan tari-tarian sudah mulai ditinggalkan di perkotaan diganti dengan menonton film. Dalam hal ini, film dapat memberikan efek pergeseran budaya masyarakat urban (Ardanareswari 2018:136). Artinya, gaya hidup Barat ini seolah diterima begitu saja di Kota Yogyakarta.
Masyarakat Yogyakarta tidak menganggap budaya ini sebagai bentuk atau kepanjangan dari warisan kolonialis.

Penggunaan gaya hidup Barat, termasuk gaya berpakaian, turut diikuti oleh bangsawan di lingkungan keraton. Gaya hidup Barat menjadi bagian dari keseharian perempuan keraton. Alhasil, ketika keraton menjadi kiblat masyarakat, maka proses adopsi seluruh simbol yang digunakannya berlangsung dengan mudah. Hal ini terjadi pada unsur pakaian-pakaian keraton, menumenu makanan, simbol status sosial, seperti parasol, dan kecohan.

Simbol budaya Barat yang menjadi roh dalam keseharian perempuan Yogyakarta merupakan bagian dari cultural citizenship. Nordholt mengatakan bahwa cultural citizenship sudah berkembang di Hindia-Belanda sejak akhir abad ke-19 saat terbentuknya masyarakat kosmopolis (Ariwibowo 2019:55). Pada awal abad ke-20, budaya Barat yang dibawa oleh masyarakat kolonial dibungkus dengan modernitas, seperti menonton bioskop, membaca buku, menggunakan pakaian ala Eropa. Wajar jika pada masa kemerdekaan simbol tersebut lolos dari amuk masyarakat koloni yang ingin melepaskan diri dari simbol kolonial.

Pada masa setelah kemerdekaan, masyarakat banyak mempraktikkan model penampilan dan gaya hidup yang telah diwariskan orang Eropa masa kolonial. Faktor-faktor pride atas pelabelan intelektual, status masyarakat atas, priyayi baru, seluruhnya turut mendukung kuatnya praktek budaya Barat yang dilakukan oleh perempuan 
Yogyakarta (Khasanah dan Afiyanto 2017:159).

Fenomena menarik terjadi di sekitar Malioboro, tempat perempuan Yogyakarta lebih banyak menggunakan simbol kolonial, di tempat yang sama upaya amuk dan pemutusan simbol kolonial secara fisik masih berlangsung secara masif. Pelabelan tidak nasionalis menjadi ujung tombak untuk menghakimi bahwa simbol tersebut berhak atau tidak untuk diberi label warisan kolonial. Fenomena ini menarik ketika budaya sebagai simbol yang tidak terlihat dan menjadi ruang yang aman bagi perempuan Yogyakarta untuk mengekspresikan diri mereka, serta ruang yang aman juga bagi pewarisan gaya hidup Barat pada masyarakat koloni tanpa ada gesekan secara fisik.

\section{Gaya Hidup Barat dan Eksistensi Perempuan Yogyakarta Tahun 1950an}

Masifnya gaya hidup Barat yang sudah menjadi bagian dalam keseharian perempuan, nyatanya tetap menjadi persoalan dalam masyarakat Yogyakarta. Semangat anti kolonial memang terlihat tidak menyentuh pada penghancuran gaya hidup Barat, tetapi lokalitas dalam konteks budaya dan pendidikan mengisyaratkan bahwa gaya hidup Barat berdiri pada ruang stigma. Beberapa organisasi pendidikan, budaya, dan sosial mengambil justifikasi negatif terhadap perempuan pengguna gaya hidup Barat (Dewantara 1955). Sebaliknya, justifikasi positif diberikan pada laki-laki dengan gaya hidup Barat yang menjadi simbol intelektualitas atau modernitas.
Artikel-artikel dalam terbitan lokal Yogyakarta menunjukkan pertentangan tersebut. Perempuan pengguna gaya hidup Barat dilabeli sebagai perempuan yang kehilangan norma, tidak bersusila, kehilangan identitas, dan simbol-simbol lainnya. Umumnya lembaga pendidikan berlatar belakang agama menyerukan bahwa yang sudah dilakukan perempuan-perempuan tersebut dapat merusak moral generasi penerus. Perempuan adalah calon ibu yang akan melahirkan anak-anaknya. Mereka berasumsi jika seorang ibu memiliki norma, nilai, dan perilaku yang tidak sesuai dengan yang dianut nenek moyang, maka ia melahirkan generasi penerus yang lupa identitasnya.

Upaya mengawal moralitas anti Barat untuk perempuan dilakukan Taman Siswa membuat aturan bagi siswinya, yaitu: "Djanganlah mengidzinkan anak perempoean bepergian sendirian dengan anak laki-laki, kendatipoen waktoe siang. Kalau perloe pergi dengan anak laki-laki, baiklah bawa teman satoe lagi, baik perempoean maoepoen laki-laki... Djadi seharoesnja moesti ada tiga orang sedikitnja boleh bersama-sama. Kaloe waktoe sang Matahari jaitoe Batara Maha Controleur sodah pergi tidak baik gadis-gadis berpergian, kalau tidak dihantarkan orang toea..." (Wasita 1928).

Namun selanjutnya, langkah kompromi dilakukan oleh Ki Hajar Dewantara dengan Taman Siswa. Taman Siswa memilih lebih bernegosiasi dengan gaya hidup Barat dalam keseharian perempuan Yogyakarta. Beberapa gambar para siswi Taman Siswa menggunakan 
Handep Jurnal Sejarah dan Budaya Vol. 5, No. 1, Desember 2021, hlm. 97-110

pakaian ala Barat termuat dalam beberapa terbitan. Hal tersebut merupakan simbol telah lepasnya pagar domestikasi yang selama ini dilanggengkan oleh budaya patriarki.

Kongres Perempuan pertama di Yogyakarta pada tahun 1928 dapat dilihat sebagai bentuk pengaruh modernitas terhadap perkembangan keseharian perempuan Yogyakarta. Beberapa dokumentasi kongres tersebut menunjukkan perempuan juga melakukan negosiasi dengan modernitas.

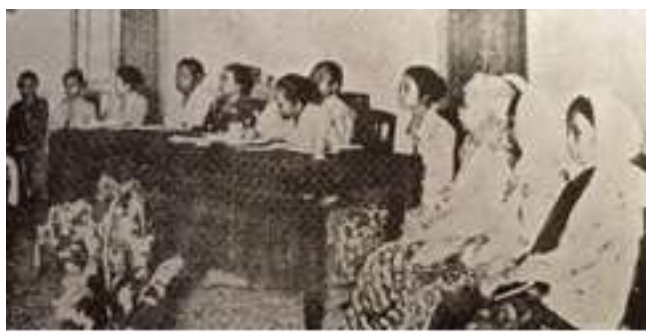

Gambar 4. Kongres Perempuan Yogyakarta. Sumber: www.kitlv.nl.

Hakikatnya memang tidak mungkin untuk menyangkal atau menolak penetrasi dari modernitas yang dibawa oleh kaum kolonial. Penerimaan atas gaya hidup Barat oleh perempuan Yogyakarta ditunjang oleh kesadaran bahwa modernitas yang dibawa dari luar membawa paham kesetaraan untuk perempuan Yogyakarta. Dasar ini yang menjadikan kongres perempuan tetap menggunakan simbol ketimurannya, seperti: pakaian dan perlengkapannya, tetapi di sisi lain juga menggunakan simbol gaya hidup Barat, seperti gaya hidup dan keterbukaan ideologi.

Penggunaan gaya hidup Barat yang notabene warisan kolonial dan dalam perjalanannya dilabeli negatif oleh beberapa kelompok masyarakat di Yogyakarta, nyatanya mampu menghasilkan organisasi-organisasi perempuan yang memiliki peranan luar biasa. Organisasi ini dapat dilihat baik sebelum kemerdekaan atau sesudah kemerdekaan.

Organisasi perempuan mampu mendorong perempuan-perempuan Yogyakarta untuk memeroleh kesempatan pendidikan yang selama ini dibatasi oleh budaya patriaki dengan pola pikir konco wingking yang membawa ketimpangan berpendidikan antara laki-laki dan perempuan.

Organisasi perempuan turut menyebarkan pendidikan bagi kaum perempuan melalui kursus keterampilan secara gratis. Terlepas dari pro dan kontra dalam masyarakat, perempuan Yogyakarta terutama di perkotaan, mampu membuktikan bahwa gaya hidup Barat memberikan pengaruh baik buat diri sendiri dan juga perempuan lainnya. Terbukti dari peminat pendidikan dari kaum perempuan yang semakin tinggi.

Konsekuensi lanjutan dari pendidikan adalah keinginan perempuan Yogyakarta untuk berkompetisi dalam profesi. Umumnya profesi-profesi di ruang publik hanya diisi oleh kaum laki-laki. Kontes mode di sepanjang tahun 1950an memunculkan simbol kesetaraan profesi yang dibawa oleh perempuan Yogyakarta seperti penggunaan kamera, pakaian pejabat daerah, dan pakaian olahraga oleh perempuan Yogyakarta. Simbol-simbol tersebut menunjukkan ekspresi dari keinginan perempuan Yogyakarta atas kesetaraannya dengan kaum laki-laki.

Angin segar dari modernitas inilah yang digunakan perempuan Yogyakarta yang melek pendidikan untuk mem- 
bongkar kelanggengan patriarki tersebut. Alhasil di akhir tahun 1950an, muncul iklan-iklan lowongan pekerjaan untuk perempuan Yogyakarta, seperti bidan, guru, pegawai pemerintah dan tukang jahit di berbagai terbitan lokal. Kesempatan berkompetisi dalam profesi yang sama dengan laki-laki bukan ditafsirkan sebagai kesamaan kuantitas ragam profesi yang ditawarkan.

Beragam simbol yang ditampilkan oleh perempuan Yogyakarta menunjukkan ekspresi keinginan mereka. Awalnya penggunaan gaya hidup Barat sebelum kemerdekaan dianggap sebagai bentuk negosiasi masyarakat bumiputra dengan pemerintah kolonial Hindia-Belanda. Hal ini merupakan upaya untuk menghindarkan kekerasan fisik yang dapat saja muncul sebagai akibat dari dikotomi kolonial dan koloni. Dalam perjalanannya, penetrasi budaya berlangsung dalam jalur berbeda dengan penetrasi politik, ekonomi, dan lainnya. Nyatanya masyarakat di Kota Yogyakarta, khususnya perempuan menikmati negosiasi budaya yang ditawarkan kaum kolonial sebagai sebuah bentuk modernitas. Budaya baru yang lebih egaliter, minim ketimpangan gender menjadi bentuk kebiasaan dari budaya perempuan Yogyakarta.

\section{SIMPULAN}

Periode 1950an sering disebut sebagai dekade yang hilang dalam sejarah Indonesia sebagai sebuah negara baru. Semangat anti kolonial masih tinggi pada dekade ini. Tingginya semangat anti kolonial secara paradoksal dibarengi dengan masifnya gaya hidup
Barat dalam keseharian perempuan Yogyakarta.

Sentimen anti Barat di Yogyakarta yang ditandai dengan pengerusakan peninggalan kolonial secara fisik di satu sisi, berbanding terbalik dengan gaya hidup Barat yang melebur dalam kehidupan sehari-hari perempuan Yogyakarta. Umumnya, pengguna gaya hidup Barat adalah perempuan yang sudah mendapatkan internalisasi nilai-nilai modernitas. Proses internalisasi gaya hidup Barat sebenarnya sudah berkembang dalam keseharian perempuan di Kota Yogyakarta, terutama pada akhir masa kolonial. Latar belakang profesi, kemudahan akses transportasi, komunikasi dan berbagai fasilitas publik lainnya melahirkan perilaku dan gaya hidup yang khas. Demikian pula dengan tingkat pendidikan dan ekonomi yang berbeda semakin mempermudah perempuan Yogyakarta untuk beradaptasi dengan elemen-elemen modernitas yang membentuknya sebagai masyarakat perkotaan.

Penerimaan masyarakat Yogyakarta terhadap gaya hidup Barat adalah bentuk akulturasi kebudayaan. Penerimaan gaya hidup Barat dapat dilihat dari keseharian perempuan Yogyakarta seperti berwisata, menonton bioskop, membaca buku dan kontes mode. Perempuan yang mendapatkan pengaruh dari modernitas merupakan pengguna dari gaya hidup Barat. Penggunaan gaya hidup Barat tidak sekadar hanya efek modernitas, tapi juga penyampai pesan, baik tentang pemahaman gender, ringkihnya domestikasi, hingga patriarki. 
Handep Jurnal Sejarah dan Budaya Vol. 5, No. 1, Desember 2021, hlm. 97-110

\section{DAFTAR SUMBER}

Afiyanto, Hendra. 2017. Dari Kacamata hingga Kerudung Identitas Penampilan Masyarakat Yogyakarta PascaWesternisasi dan Agamaisasi (1950'an-1970'an). Ponorogo: STAINPO Press.

Amini, Mutiah. 2005. "Kontes Mode sebagai Simbol Baru Perempuan Kota Yogyakarta". Laporan Penelitian. Proyek City Symbols and Street Images: PSSAT UGM.

Anonim. 1959. "No Title." Madjalah Ibu.

Anonim. 1952. “13.” Minggu Pagi, 16.

Anonim. 1951. "Suka Duka Seorang Modiste Dewi." Minggu Pagi, 5.

Anonim. 1941. "No Title." SINPO, November.

Anonim. 1928. "No Title.” Wasita, 105.

Anonim. 1947. "No Title." Kedaulatan Rakjat.

Anonim. 1952. "No Title.” Kedaulatan Rakjat.

Anonim. 1956. "Gamawati." Madjalah Gadjah Mada, 819.

Ardanareswari, Indira. 2018. "Honorarium, Aktris, Gender: Perempuan Pekerja Seni dalam Industri Perfilman Indonesia, 1950an-1970an." Lembaran Sejarah 14(2):136.
Ariwibowo, Andika. 2019. "Perkembangan Budaya Kosmopolitan di Batavia 1905-1942." Handep: Jurnal Sejarah dan Budaya 3(1):55.

Colombijn, Freek, dan Joost Coté (ed) 2014. Cars, Conduits, and Kampongs: The Modernization of the Indonesian City, 1920-1960. Leiden: Brill.

Dewantara, Ki Hadjar. 1955. "No Title." Wasita, 227.

Hamid, Farid. 2012. "Media dan Budaya Populer.” Jurnal Komunika 15(1):11.

Idrus, Ani. 1952. "Berkunjung ke Yogya." Minggu Pagi, November, 50.

Khasanah, Nurul, dan Hendra Afiyanto. 2017. "Identitas Penampilan Masyarakat Yogyakarta 1950'an1970'an." Kodifikasia: Jurnal Penelitian Islam 11(1):159.

Nordholt, Henk Schulte (ed.). 2005. Outward Appearance. Trend Identitas, Kepentingan. Yogyakarta: LKIS.

Nordholt, Henk Schulte. 2011. "Modernity and Cultural Citizenship in the Netherlands Indies: An Illustrated Hypothesis.' Journal of Southeast Asian Studies 42(3):435.

Nurhajarini, Dwi Ratna. 2003. "Perkembangan Gaya Pakaian Perempuan Jawa di Kota 
Yogyakarta pada Awal Abad XX sampai Akhir Masa Kolonial." Tesis, Fakultas Ilmu Budaya, Universitas Gadjah Mada, Yogyakarta.

Pranowo, Yogie. 2013. "Identitas Perempuan dalam Budaya Patriarkis: Sebuah Kajian tentang Feminisme Eksistensialis Nawal El Sa'adawi dalam Novel 'Perempuan di Titik Nol”, Melintas 29(1):56.

Rahayu, Lina Meilinawati. 2018. "Representasi 'Perempuan Matang' dalam Majalah Pesona (Femina Group) Indonesia." Patanjala: Jurnal Penelitian Sejarah dan Budaya 10(3):353.

Rumini, Sri, dan Siti Sundari. 2004. Perkembangan Anak dan Remaja. Jakarta: Rineka Cipta.

Scott, Joan Wallach. 1988. Gender and Politics of History. New York: Columbia University.

Soemardjan, Selo. 2009. Perubahan Sosial di Yogyakarta. Depok: Komunitas Bambu.

Strinati, Dominic. 2004. An Introduction to Theories of Popular Culture. Leiden: Routledge.

Surjomihardjo, Abdurrachman. 2008. Kota Yogyakarta Tempo Doeloe: Sejarah Sosial 1880-1930. Jakarta: Komunitas Bambu.

Taylor, Jean Gelman. 2005. Kehidupan Sosial di Batavia. Jakarta: Komunitas Bambu. 
Handep Jurnal Sejarah dan Budaya Vol. 5, No. 1, Desember 2021, hlm. 97-110 